\title{
Spatial distribution of inselbergs in Igbajo district of Western
}

\section{Nigeria}

\author{
Matthew Afolabi ${ }^{a b}$ \\ Olayinka Ogunkoya ${ }^{a}$
}

\begin{abstract}
Inselbergs' spatial distribution is the primary focus of this study carried out in Igbajo District of Western Nigeria. Additionally, a common hypothesis that spatial distribution of inselbergs is informed by the differing modes of evolution of the landforms was also examined. Inselbergs are defined as points on the topographic sheet and satellite terrain elevation data and are thereafter subjected to point pattern analysis. Two point pattern analyses: Poisson Probability Distribution (PPD) and Nearest Neighbour Analysis (NNA) are employed to determine the pattern of inselberg distribution over space. Additional analysis focused on the relationship between regional river drainage and inselbergs' spatial distribution. Findings from the study confirmed that inselberg form a clustered distribution. The PPD results suggest that the observed distribution of inselbergs has a statistically significant difference from the expected pattern generated by the random process $\left(\chi^{2}\right.$ test statistic $=49.82>X_{\alpha, d f}^{2}=12.59(\alpha=0.05)$ and $16.81(\alpha=0.01)$. Similarly, the NNA with $a R<1$ (Nearest Neighbour Ratio, $R=0.92$ ) and $p$-value $=-2.52$, also indicated a clustered distribution. Analysis of river drainage pattern similarly revealed a cluster of high rising landforms situated in the centre of the regional watershed. It is concluded that inselberg distribution in the study area is clustered although the observed pattern does not necessarily validate or invalidate the alternative evolutionary theories.
\end{abstract}

Key Words: Inselbergs; spatial distribution; landforms; Nearest Neighbour Analysis; Poisson distribution; Western Nigeria.

${ }^{a}$ Department of Geography, Obafemi Awolowo University, Ile-Ife, 220005, Nigeria ${ }^{\mathrm{b}}$ School of Geography and Environmental Science, University of Southampton, Building 44 Highfield, SO17 1BJ Southampton, United Kingdom Corresponding Author: rafolabi@oauife.edu.ng

Ghana Journal of Geography Vol. 13 (2), 2021 pages 284-311

https://dx.doi.org/10.4314/gig.v13i2.11 
Spatial distribution of inselbergs in Igbajo district of Western Nigeria

\section{Introduction}

The earth's surface comprises complex composite features (both natural and man-made), which constitute the scenery of any area, and make up its landscape. Typically, natural landscape comprises assemblages of physical features with distinctive forms, whose characteristics tend to reflect past and present climate, and the processes that engendered the landforms (Hugget, 2007). Landforms are thus, features on any landscape that resulted from processes connected with the action of rain, rivers, winds, waves and currents, ice, endogenic forces (forces acting beneath the crust), and the rocks/geology on which these agencies act (Hugget, 2007). Landforms tend to undergo changes and evolution, and understanding the processes triggering such changes and the nature of the resulting landforms is one fundamental aim of geomorphological enquiry. Within the hard, crystalline rock terrains especially of granite or gneiss, inselbergs often stand conspicuously in many locations. These inselbergs initially attracted the interest of geomorphologists and were the focus of numerous studies in the $20^{\text {th }}$ century. Notable contributions were from Linton (1955) in Britain; Doornkamp (1968) in Uganda; Jeje (1973) and Faniran (1974) in Nigeria; King (1975) in South Africa; Ollier (1978) in Namibia; Twidale (1982) in Australia and so on. In general, the authors viewed inselbergs as residual uplands standing above the general level of a surrounding plain, which is made up of weathered materials known as regolith (Linton, 1955; Faniran, 1974). Additionally, inselbergs were considered as remnants of the denudation of a formerly extensive rock body (a pluton) shaped at the weathering front and later exposed following the stripping of regolith (Twidale, 1982; Migon, 2006).

With regard to evolution, two contrasting theories have dominated the literature on inselbergs and other related residual landforms (Thomas, 1978, Romer, 2007). The first is the theory of pediplanation and pedimentation propagated by King $(1957 ; 1975)$ while the second is the two- 
stage hypothesis of etching and stripping of weathered mantle advanced mostly by tropical geomorphologists (Budel, 1957; Jeje, 1973; Thomas, 1978; Twidale, 1998). Previous scholars were thus, positioned across the divide while a few others (e.g. Thomas, 1978; Twidale, 1998) approached the issue more cautiously based on a reasonable level of belief in the plausibility of alternative theories. In a recent report (Owens, 2014), it was argued that some fundamental questions are yet to be fully addressed following decades of study of evolution of inselbergs. Questions pertaining to the role of structural controls (e.g. faults, joints, fractures) on inselberg development as well as the kind of changes these landforms undergo from initial exhumation to advance form are not fully explored. Inselbergs tend to manifest variety of morphology and it has been argued that the different morphologies are succession forms from initiation to eventual destruction (Twidale, 1998; Fig. 1). Given that these landforms are relatively old and believed to have been produced by cycles of denudation of the order of $10^{7}$ years or longer (Thomas, 1994), any prospect of direct observation of their development, to all intents and purposes, is unrealistic. This therefore implies that reference is made to aspects of their current morphology, geology, and distribution pattern for inference on probable processes responsible for their evolution. 


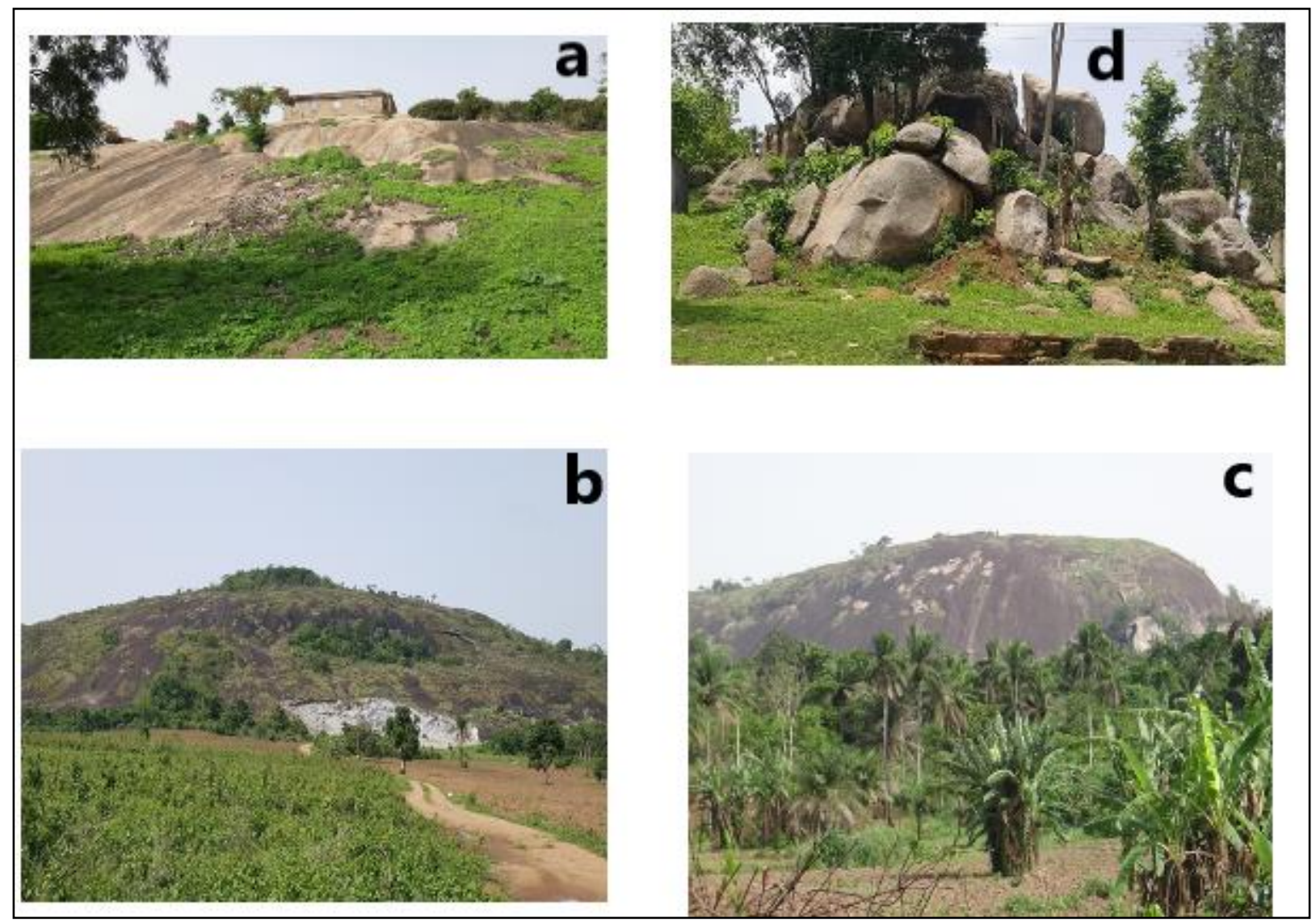

Figure 1: Various inselberg morphologies observed in the present study site. (a) is an emergent dome platform or ruware (e.g. Twidale and Bourne, 1976); (b) is an elongated massive inselberg or whaleback (e.g. Jeje, 1973); (c) is a dome inselberg or bornhardt (Twidale and Bourne, 1975) rising above the forested landscape; (d) a castellated inselberg or tor (e.g. Thomas, 1994). It has been argued that the long-term evolution of the landforms could follow in the sequence above (i.e. $\mathrm{a}-\mathrm{d}$ ) from its emergence to eventual destruction.

It has been shown that spatial distribution of inselbergs could provide some hints regarding likely processes behind their evolution (Faniran, 1974; Romer, 2005). The first documentation in this regard was by Faniran (1974), who argued for the deployment of statistical analysis to elucidate contentious issues pertaining to inselberg evolution in an empirical manner. The approach was later adopted in a study of inselbergs in Zimbabwe (Romer, 2005). The previous author carried out his study in the basement complex terrain of Western Nigeria (Faniran, 1974). The main argument underpinning spatial pattern analysis (Faniran, 1974), is that distribution pattern can be related 
directly to specific process pathway. In this regard, it was argued that if inselbergs were the results of pediplanation and scarp retreat as espoused by King (1975), they should have been located in clusters around and along major drainage divides in a region. On the other hand, if inselbergs were the results of two-stage process of etching and stripping (Thomas, 1978), they should have occurred randomly in the region with no obvious physiographic inclination. These were the research questions of Faniran (1974) study. The results indicated patterns ranging from random to regular leading to the affirmation of the two-stage hypothesis for the evolution of the inselbergs in Western Nigeria.

However, in a more recent spatial pattern analysis of inselbergs, the result revealed a tendency towards a clustered distribution (Romer, 2005). Curiously, the author alluded that the two-stage process is the valid process behind the development of the landforms. This, therefore, raises several important questions. The first question is whether spatial distribution is good enough to assist in determining the most plausible evolution process of inselbergs. Similarly, it is also debatable whether a straightforward set of alternative hypotheses of inselberg development can be tied to observed distribution pattern as was previously espoused. The final issue has to do with the role of spatial scale of enquiry. Importantly, the first study covered the entire basement terrain of Western Nigeria, which in today's setting consists of the states of Southwestern Nigeria (except the coastal Lagos and parts of Ogun and Ondo States) and part of Kwara State in North-Central Nigeria. Within these zones are distinct plutons and massifs built in crystalline rocks such as Oyo north massif, Idanre massif, Ekiti massif, Akoko massif, Igbajo massif, among others (Thomas, 1966, 1994; Jeje, 1973; Faniran, 1974; Afolabi and Ogunkoya, 2018). In between some zones where there are inselbergs and related forms, lie huge expanses of the landscape with very little or no presence of such landforms. It is, therefore, possible that the large spatial scale involved in the 
analysis (Faniran, 1974) informed the random pattern observed. In contrast, in the subsequent work of Romer (2005), which focused on a single granitic landscape in southern Zimbabwe, the distribution pattern was not seen to be random. The present study is motivated by the need to advance this idea at the scale of a single granitic body (pluton). By so doing, the capacity of the analysis of spatial distribution of inselbergs to provide answers to questions pertaining to their evolution would be further explored.

In addition to spatial distribution, the situation of individual inselbergs or inselberg clusters in relation to the regional drainage network also provides added insight. Inselbergs' situation anywhere with no obvious physiographic bias would appear to suggest structurally controlled subsurface evolution (Jeje, 1973). In the case where clustering of inselbergs is around regional drainage divide, this was held to account for evolution of the landforms via scarp retreat. This is because denudation of the uplifted rock mass would normally proceed from the edge towards the centre thus leaving residual inselbergs in the centre following prolonged degradation. Therefore, a visualization of inselbergs' positions within the regional river drainage tend to provide further insight into their mode of evolution.

Overall, the primary objective of the study is to determine the spatial distribution of inselbergs in Igbajo District of Western Nigeria. The second goal is to explore the spatial distribution of the inselbergs to draw inference on the probable processes behind their evolution.

\section{Research principles and hypothesis}

One major area of interest of geographic enquiry is the distribution of phenomena over space. Two techniques have featured prominently in spatial pattern analysis. Quadrat analysis, which requires enumeration of points per cell, and the nearest neighbour analyses, which entail direct 
measurement of spacing between points. The main thrust of these analyses is the concept of random distribution (Silk, 1979; Rogerson, 2001). A random distribution is that in which for a set of points located over a defined area, any point has had equal chance of occurring in any sub-area as any other point, and the placement of a point on a particular sub-area has had no influence on the occurrence of another point in any other sub-area (Clark and Evans, 1954). Other patterns of distribution are clustered (characterized by a set of closely packed points in few locations), and regular forms (characterized by equidistant pattern of points) (Shaw and Wheeler, 1994).

The Poisson Probability Distribution (PPD) technique has long been identified as a veritable method of point pattern analysis and it was Clark and Evans (1954) that first mentioned the use of PPD as a tool for spatial analysis of point patterns. The method entails the application of the Poisson formula to determine probability of points per quadrat following the imposition of a number of equal-sized quadrats on any area of interest. Additionally, the Chi square distribution $\left(\chi^{2}\right)$ technique is normally employed as a follow up statistical analysis to test the significance of the observed distribution from the expected distribution, which is one generated by random occurrence. The notation of the Poisson probability and the $\chi^{2}$ analytical methods are given as follows:

$P(X=k)=e^{-\Lambda} \Lambda^{k} / k !$

where $P(X=k)$ represents the probability of ' $X$ ' number of quadrats receiving ' $k$ ' number of points.

' $K$ ' is the density of points per quadrats over the entire area denoted by $\kappa=\frac{n}{m}$ ' $n$ ' and ' $m$ ' respectively representing total number of points and number of quadrat cells involved in the analysis.

' $k$ ' represents the number of observed points per cell in the distribution ' $e$ ' $=2.71828$ is a constant and the base of natural logarithms. 
The application of the formula to all number of points scenarios starting from zero would yield the expected number of quadrats containing appropriate number of points when the probability values are multiplied by the total number of quadrats as given below:

$$
E(X=k)=P(X=k) * m
$$

where $E(X=k)$ is the expected number of quadrats containing $k$ points.

The results in columns for observed and expected number of quadrats containing ' $\mathrm{k}$ ' number of points can thereafter be subjected to the $\chi^{2}$ test to evaluate the significance of the departure of observed distribution from a random pattern using the formula outlined below:

$$
X_{v}^{2}=\sum_{i=1}^{n}\left(\frac{\left(o_{i}-e_{i}\right)^{2}}{e_{i}}\right)
$$

where $X_{v}^{2}$ is the notation for chi square at ' $v$ ' degree of freedom.

$$
\text { 'o }{ }_{i} \text { ' and ' } e_{i} \text { ' respectively the observed and expected number of quadrats with ' } k \text { ' number }
$$

of points.

A major concern of the quadrat analysis is the challenge of determining the optimum size of quadrats. In essence, if the cell size is too small, there could be many empty cells such that if clustering exists on all but the smallest spatial scales, such a pattern might be missed. Conversely, if the cell size is too large, certain patterns that occur within cells may be missed (Rogerson, 2001). Silk (1979) proposed that the quadrat should be small relative to the size of the study area and suggested an optimum number of between 50 and 100 grid cells. Rogerson (2001) suggested an optimal quadrat size of two points per quadrats. A proposal that quadrat analysis be carried out at variety of cell sizes to ensure comparison of results was also made (Silk, 1979). Whereas the 
highlighted quadrat size issue considerably limits the application of the Poisson technique in point pattern analysis, the same cannot be said of the Nearest Neighbour Analytical technique.

The Nearest Neighbour Analysis (hereafter NNA) has a rich literature to back up its application in the analysis of spatial point pattern (Clark and Evans, 1954; Faniran, 1974). The introduction of the technique into analysis of the spatial point pattern was by Ecologists, Clark, and Evans (1954). In essence, the NNA employs distance in two-dimensional space from one individual point to another within a particular region of interest. This ensures that the required variable for pattern analysis is distance and not square quadrats, and consequently eliminates the impact of quadrat size on the outcome of spatial point pattern analysis. The outcome of NNA is usually the determination of the value of $\mathrm{R}$, which ranges normally from $0-2.15$, and on which scale ' 0 ' indicates total clustering of points at the same location while the other extreme, 2.15 indicates a perfect regularity of points into an hexagonal pattern (Faniran, 1974). A value of ' 1 ' implies randomness and is usually the reference value of the statistical test. The technique, denoted with 'Average Nearest Neighbour' in the ArcGIS environment has a number of notations as highlighted below:

The average nearest neighbour ratio is given as: $A N N=\frac{\overline{D o}}{\overline{D e}}$

Where $\overline{D o}$ is the observed mean distance between each feature and its nearest neighbour and $\overline{D e}$ is the expected mean distance between each point and its nearest neighbour.

The $z$-score for the statistic is calculated thus: $Z=\frac{\overline{D o}-\overline{D e}}{S E}$

where SE, the standard error is estimated thus: $S E=\frac{0.26136}{\sqrt{n^{2}} / A}$

where ' $n$ ' corresponds to the total number of points and ' $A$ ' denotes area of region of interest.

For the present study, the null hypothesis was set up as follows:

$\mathbf{H}_{0}$ : Location of inselbergs is random and independent.

H1: Location of inselbergs neither random nor independent.

The hypothesis was tested using the PPD and the NNA. 
Spatial distribution of inselbergs in Igbajo district of Western Nigeria

\section{Study Area}

The study was carried out in Igbajo District of Western Nigeria. The study site is situated approximately $49 \mathrm{~km}$ north of Ilesa and $50 \mathrm{~km}$ northeast of Osogbo, two major settlements in the region. The area lies between latitudes $7^{0} 53^{\prime}$ and $7^{0} 57^{\prime} \mathrm{N}$, and longitudes $4^{0} 41^{\prime}$ and $4^{0} 52^{\prime} \mathrm{E}$ (Fig. 2). The landscape comprises of inselbergs within an extensive weathered surface, which has been variably dissected by surface drainage (Burke and Durotoye, 1970; Thomas, 1994). The topography is a rugged one, characterised by a hill and valley landscape with local relief in excess of $100 \mathrm{~m}$ in certain locations (Afolabi and Ogunkoya, 2018). The climate is humid tropical characterised by distinct dry season period while the region has a rainforest vegetation, which has become degraded in favour of agriculture, lumbering and fuelwood harvesting.

The geology of the area comprises rocks of plutonic origin referred to as the Igbajo granitic pluton, which forms part of the Precambrian Basement Complex of Western Nigeria (de Swardt, 1953; Rahaman, 1976). The Igbajo granite is bounded to the west by granite-gneiss; to the southeast by undifferentiated gneissic migmatite, while to the northeast, it is bounded by schist and epidiorite complex (Fig. 3). The granites are coarse grained and slightly porphyritic, although some gneissic foliation is noticeable in the marginal areas (de Swardt, 1953). The pluton formed a discrete body of about $120 \mathrm{~km}^{2}$ in areal extent as observed in satellite data (Fig. 5). Physical observations of the rock samples revealed alkali-feldspars, quartz, and biotite as the main mineral constituents and was validated by petrographic analysis which revealed the preponderance of quartz, plagioclase (oligoclase variant) and microcline in the rock samples (Afolabi et al., 2013). Quartz, k-feldspars, and microcline are known to be relatively resistant to chemical denudation (e.g. Pye et al., 1984; Romer, 2005), hence the plutonic body outcropped in several places as inselbergs. 
For this study, Igbajo District was seen as the ideal location for various reasons. Firstly, the selected region is known for its abundance of inselbergs (Burke and Durotoye, 1970; Thomas, 1994). It is also a subset of the Western Nigerian basement region, which was the focus of the earlier reviewed study (Faniran, 1974) and thus, provides an avenue to evaluate the influence of spatial scale on the observed distribution pattern. The inselbergs of the study site have not been the focus of extensive geomorphological enquiry except for the one, which examined the incidence of rock boulder slide (Burke and Durotoye, 1970), as well as general reference in a broad study (Thomas, 1994).

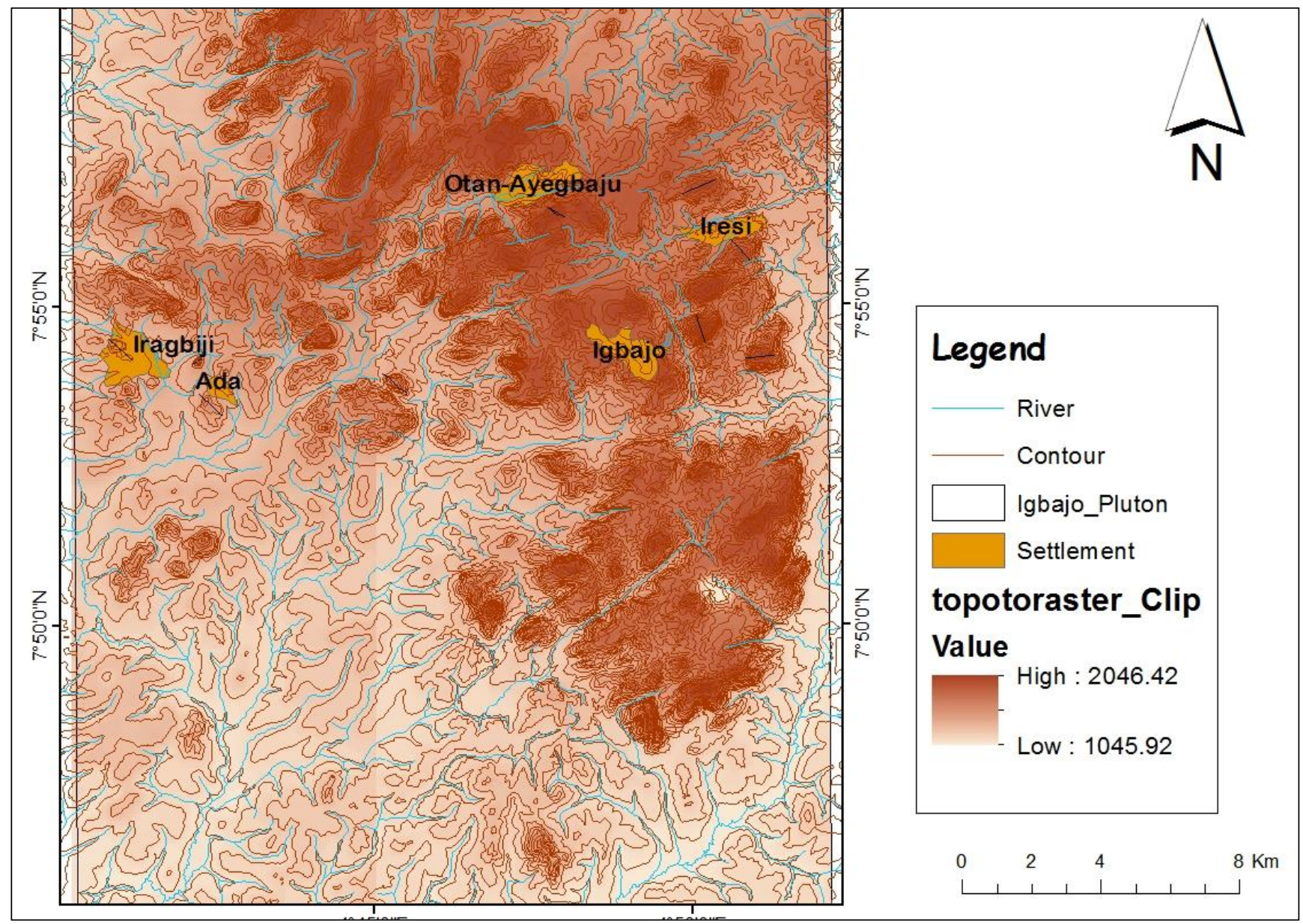

Figure 2: The Study site 


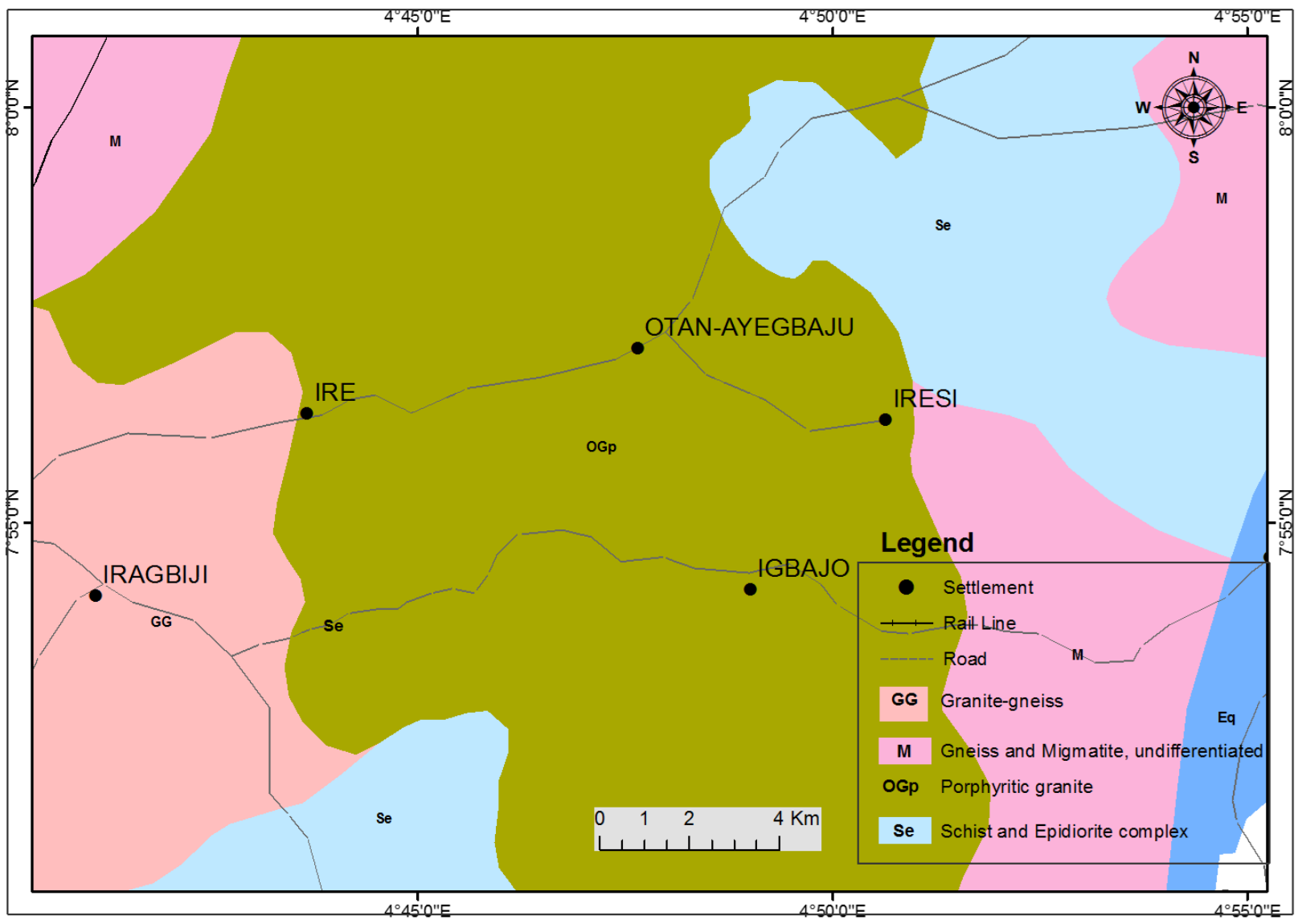

Figure 3: Geology of the study site

\section{Methods and Materials}

The study employed two-point pattern analytical techniques to facilitate the determination of the spatial pattern of distribution of inselbergs: PPD and the NNA. The topographic data and satellite data of the area formed the baseline information for this study with the former providing information for inselberg enumeration and the latter providing additional information for inselberg identification and the drainage network analysis.

For the quadrat analysis with Poisson probability technique, a number of steps were followed: 
i. The topographic map of the study area was digitized to derive the contour elevation and other topographic feature of the study area in the Geographic Information System (GIS) environment.

ii. ArcGIS tool, 'Create Fishnet' in 'Data Management' toolbox was used to impose a set of regular grid lines on the study area.

iii. Square grid measuring $2 \mathrm{~km} * 2 \mathrm{~km}$ were imposed on the study area in first instance, while grid cells measuring $1.5 \mathrm{~km} * 1.5 \mathrm{~km}$ were imposed in the second attempt. Grid size was varied in order to evaluate if the size of the grid cells had an effect on observed distribution pattern in common with the approach of Romer (2005).

iv. Inselbergs were defined as landforms represented by minimum of four (4) closely spaced contour lines. The topographic map has contour interval of $10 \mathrm{~m}$. This implies that, for a landform to be defined as inselberg, it must attain a minimum relative relief of about $30 \mathrm{~m}$ (for instance assume a peak of $580 \mathrm{~m}$ asl and base of $550 \mathrm{~m}$ asl for an inselberg with 4 contour lines $550 \mathrm{~m} ; 560 \mathrm{~m} ; 570 \mathrm{~m}$ and $580 \mathrm{~m}$. The absolute height of the landform is $580 \mathrm{~m}$ (i.e. peak) minus $550 \mathrm{~m}$ (i.e. base), that equals $30 \mathrm{~m}$ ), and this proposition is largely in conformity with previous studies in the area (Faniran, 1974; Afolabi and Ogunkoya, 2018).

v. The identified inselbergs were defined as points and the number of points per quadrat were enumerated for the each of the grid cells created.

vi. Some inselbergs extended across the boundary of two contiguous grid cells. The point was carefully emplaced in the cell where the crest or peak of the landform is situated as validated with the satellite data. 
vii. A frequency distribution of the number of quadrats was computed for each grid cell. The generated frequency distribution of counts per quadrat is shown in Tables $\mathbf{1}$ and $\mathbf{2}$ for the two distinct grid sizes.

viii. Poisson Probability formula was, thereafter, employed to determine the expected number of points per quadrat under a random process.

ix. Finally, chi square $\left(X^{2}\right)$ technique was applied to determine the significance of the difference between observed inselbergs' distribution and the hypothetical distribution generated by a random process (Tables 3 and 4).

Secondly, NNA was used to test the randomness of location of inselbergs in the study area:

i. The inselberg points defined on the topographic data, in the GIS environment formed the input data.

ii. The distance from an individual point (inselberg) to its nearest neighbour provided the baseline data for the analysis.

iii. Distance between points was measured in Euclidean format.

iv. The value of mean distance to nearest neighbour was obtained (observed mean distance).

v. The mean distance to the nearest neighbour under a random process was determined (expected mean distance).

vi. The ratio $(\mathrm{R})$ of the observed mean distance to the expected mean distance was determined and is the index of randomness (cf. Clark and Evans, 1954).

vii. The analysis was carried out with the aid of the 'spatial statistic tool' of 'Average Nearest Neighbour' within the ArcGIS software. 
Thirdly, an analysis of the river drainage network of the study area was undertaken in an attempt to visualise the spatial positioning of inselbergs with respect to river channel network. To achieve this, the SRTM DTED (Shuttle Radar Topography Mission - Digital Terrain Elevation Data) was processed to generate the DEM (Digital Elevation Model) of the area. The SRTM data was obtained from open-source earth observation data repository, Earth Explorer of the USGS (United States Geological Survey). Within the ArcGIS environment, the study area was clipped out and the DEM was generated while Arc Hydro Tools, an extension within the ESRI's ArcGIS was employed to generate the drainage network of the area.

\section{Results}

\section{Quadrat analysis with PPD}

In the first part of this analysis, attempt was made to employ the PPD technique to determine the expected outcomes regarding the number of grid cells having $0,1,2 \ldots, \mathrm{n}$ number of points under a random process $\left(\mathrm{e}_{\mathrm{i}}\right)$. The default number of points, otherwise known as 'observed points $\left(\mathrm{O}_{\mathrm{i}}\right)$ ' is the corresponding frequency of grid cells with $0,1,2 \ldots \ldots, \mathrm{n}$ points as derived via enumeration (Table 1 and 2). Table 1 (grid cells measuring $2 * 2 \mathrm{~km}^{2}$ ) shows the observed number of grid cells with no points to be elevated above the expected number of cells. In contrast, the number of observed grid cells with 1 point and 2 points fall short of the expected number of grid cells in a random process. For the grid cells having higher number of points, 3, 4, and 5, the two columns (i.e. observed and expected frequency) are largely correlated. The pattern shown by Table 2 (grid cells measuring $1.5 * 1.5 \mathrm{~km}^{2}$ ) is similar to Table 1 . Thus, we can conclude that the size of quadrat has not had any decisive influence on the pattern of points, a conclusion that tallies with a previous study by (Romer, 2005). 
Table 1: Frequency distribution of inselberg points per quadrats with $2 * 2\left(\mathrm{~km}^{2}\right)$ grid cells

\begin{tabular}{lll}
\hline Number of points (n) & Number of quadrats (oi) & $\begin{array}{l}\text { Expected number of } \\
\text { quadrats (ei) }\end{array}$ \\
\hline 0 & 44 & 26 \\
1 & 38 & 47 \\
2 & 31 & 43 \\
3 & 21 & 26 \\
4 & 11 & 12 \\
5 & 9 & 4 \\
$\geq 6$ & 6 & 1 \\
\hline n: 292 & m: 160 & $\kappa: 1.825$ \\
\hline
\end{tabular}

Table 2: Frequency distribution of inselbergs points per quadrats with $1.5^{*} 1.5\left(\mathrm{~km}^{2}\right)$ grid cells

\begin{tabular}{llll}
\hline Number of points (n) & Number of quadrats (oi) & $\begin{array}{l}\text { Expected number of } \\
\text { quadrats (ei) }\end{array}$ \\
\hline 0 & 110 & 92 \\
1 & 85 & 100 \\
2 & 41 & 54 \\
3 & 22 & 19 \\
4 & 7 & 5 \\
$\geq 5$ & 6 & 1 \\
\hline n: 292 & m: 271 & $\kappa: 1.077$ \\
\hline
\end{tabular}

Validation of PPD with the $X^{2}$

The $X^{2}$ test was carried out to test the significance of the departure of observed distribution from a randomly generated process. The results of the $X^{2}$ test for the two sets of grid squares are contained in Table $3\left(2 * 2 \mathrm{~km}^{2}\right.$ grid cells) and Table $4\left(1.5 * 1.5 \mathrm{~km}^{2}\right.$ grid cells). For this analysis, a test statistic that falls within the acceptance region is interpreted to mean that the difference between observed distribution and expected distribution is not statistically significant, hence, $\mathrm{H}_{0}$ is accepted. In the event of a rejection of $\mathrm{H}_{0}$ when observed distribution falls outside the acceptance region, it is implied that there is a statistically significant difference between the observed distribution of points 
and the expected points distributed in a random process. Accordingly, we define the acceptance region as:

$X_{V}^{2}<X^{2}(\alpha,\{\mathrm{v}-1\}$ d.f. $)$

Where ' $\mathrm{v}$ ' represents the number of classes in the frequency distribution table.

' $\alpha$ ' represents the chosen level of significance which in this study are 0.05 and 0.01 .

'd.f.' is the degree of freedom and is obtained as shown in the above notation.

The value on the left hand side of the notation was obtained from equation (3) while the values on the right hand side were obtained from the statistical table.

The highlight of Table 3 is that $X^{2}$ test statistic 49.82 is greater than the statistical table $X^{2}$ value of 12.59 (for $\alpha=0.05$ ) and 16.81 (for $\alpha=0.01$ ), thus implying that the result falls outside the acceptance region. Therefore, $\mathrm{H}_{0}$ was rejected and it was concluded that statistical evidence suggests that the location of inselbergs is neither random nor independent. Similarly, Table 4 shows that the $X^{2}$ test statistic 35.17 is greater than the statistical table $X^{2}$ value of 11.07 (for $\alpha=$ 0.05 ) and 15.09 (for $\alpha=0.01$ ), thus implying that the result falls outside the acceptance region. Therefore, $\mathrm{H}_{0}$ was rejected and it was concluded that there is a statistically significant difference between the observed distribution and the expected distribution. This, therefore, validates the alternative hypothesis that the occurrence of inselbergs in the study area is neither random nor independent. In addition, the fact that similar results were obtained from the both tests more or less eliminate the impact of grid size on the analysis (Romer, 2005). 
Table 3: Poisson and Chi-square statistical analysis of distribution of inselbergs with $2 * 2\left(\mathrm{~km}^{2}\right)$ grid cells.

\begin{tabular}{llll}
\hline \multicolumn{1}{c}{ Number of Points } & Oi & Ei & $(\text { Oi-ei })^{2} / \mathrm{ei}$ \\
\hline 0 & 44 & 26 & 12.46 \\
1 & 38 & 47 & 1.72 \\
2 & 31 & 43 & 3.35 \\
3 & 21 & 26 & 0.96 \\
4 & 11 & 12 & 0.08 \\
5 & 9 & 4 & 6.25 \\
$\geq 6$ & 6 & 1 & 25.0 \\
\hline $\mathrm{n}: 292$ & $\mathrm{~m}: 160$ & $\chi_{6}^{2}=49.82$ \\
$\Lambda=1.825$ & \multicolumn{3}{l}{${ }^{2}($ Table $)=12.59(0.05)$ and $16.81(0.01)$} \\
\hline $\mathrm{X}_{6}^{2}=49.82>\chi^{2}(\alpha=0.05$ and $0.01,6 \mathrm{df})=12.59$ and 16.81 respectively \\
Decision: Reject $\mathrm{H}_{0}$ & & \\
\hline
\end{tabular}

Table 4: Poisson and Chi-square statistical analysis of distribution of inselbergs with $1.5^{*} 1.5\left(\mathrm{~km}^{2}\right)$ grid cells

\begin{tabular}{llll}
\hline \multicolumn{1}{c}{ Number of Points } & Oi & Ei & $(\text { Oi-ei })^{2} / \mathrm{ei}$ \\
\hline 0 & 110 & 92 & 3.52 \\
1 & 85 & 100 & 2.25 \\
2 & 41 & 54 & 3.13 \\
3 & 22 & 19 & 0.47 \\
4 & 7 & 5 & 0.8 \\
$\geq 5$ & 6 & 1 & 25.0 \\
\hline$\sum \mathrm{n}: 292$ & $\mathrm{~m}: 271$ & $\chi 5^{2}($ Table $)=11.07(0.05)$ and $15.09(0.01)$ \\
$\Lambda=1.077$ & & \\
\hline $\mathrm{X}_{5}^{2}=35.17>\chi^{2}(\alpha=0.05$ and $0.01,5 \mathrm{df})=11.07$ and 15.09 respectively \\
Decision: Reject $\mathrm{H}_{0}$
\end{tabular}

\section{Nearest Neighbour Analysis (NNA)}

The second part of the analysis involves the application of the NNA to evaluate the pattern of distribution of inselbergs. As highlighted earlier the NNA is operationalised based on the average of the nearest distance between any one point and other points, thereby overcoming the challenge that comes with employing variable size of grid cells in point pattern analysis. In addition, the three critical values often definitive in any NNA procedure are: 
i. $\quad 0$ (zero): absolute clustering of points.

ii. 1 : Perfect randomness of points.

iii. 2.15: perfect regularity of points.

Other results are usually related to the three values outlined here in order to arrive at a decision on observed spatial distribution of objects.

The result (Fig. 4) obtained from the NNA include NNR (Nearest Neighbour Ratio) or R (0.92); z-score (-2.52); and p-value (0.012). In an NNA, p-value is the probability that observed pattern was created by random processes and when it is very small (i.e. < 0.05), it indicates the unlikelihood of an observed pattern being the result of a random process. Similarly, a higher value of $\mathrm{z}$ (i.e. where $\mathrm{z}>2.50$ or $<-2.50$ ) indicates a tendency towards clustering. The result of the study with a ' $R$ ' of 0.92 is therefore indicative of a tendency towards a clustered distribution of the inselbergs. The NNA, in agreeing with the PPD and $\chi^{2}$ procedures highlighted earlier, has shown that the outcome has not been influenced by the technique of spatial analysis employed an outcome that is consistent with Romer (2005) but differs markedly from the results obtained in Faniran (1974). 


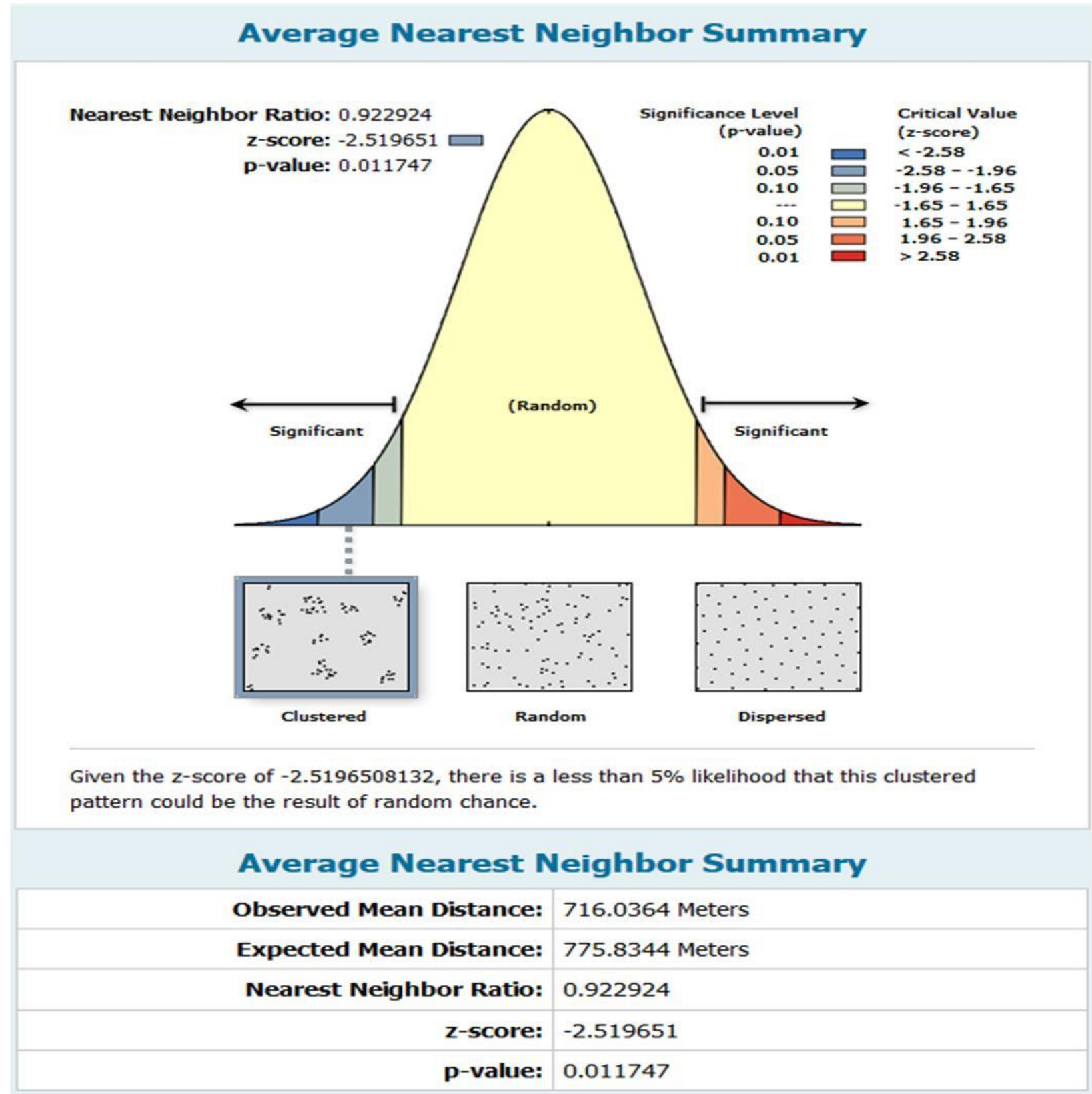

Figure 4: Nearest Neighbour Analysis summary indicating the clustered distribution of the inselberg points

\section{Drainage network and inselbergs distribution}

Attempt was made to evaluate the relationship between river channel network and inselbergs distribution in order to establish if the inselbergs' spatial pattern depicts locational bias towards 
particular section within the regional drainage network. The result (Figs. 5 and 6) showed that the Igbajo massif is a regional headwater from where rivers diverge into various directions. The rivers have cut through the rock mass in various places creating lowland areas including the location of Otan-Ayegbaju settlement. The fringes of the rock body appeared to have suffered greater denudation as weak planes were exploited by streams, which are presently characterised by greater channel network density. The visual interpretation of the terrain suggests the modes of evolution involving fluvial incision and erosion, valley widening and scarp retreat (King, 1975) thus, casting doubts on the landforms being initiated in the subsurface and later exposed.

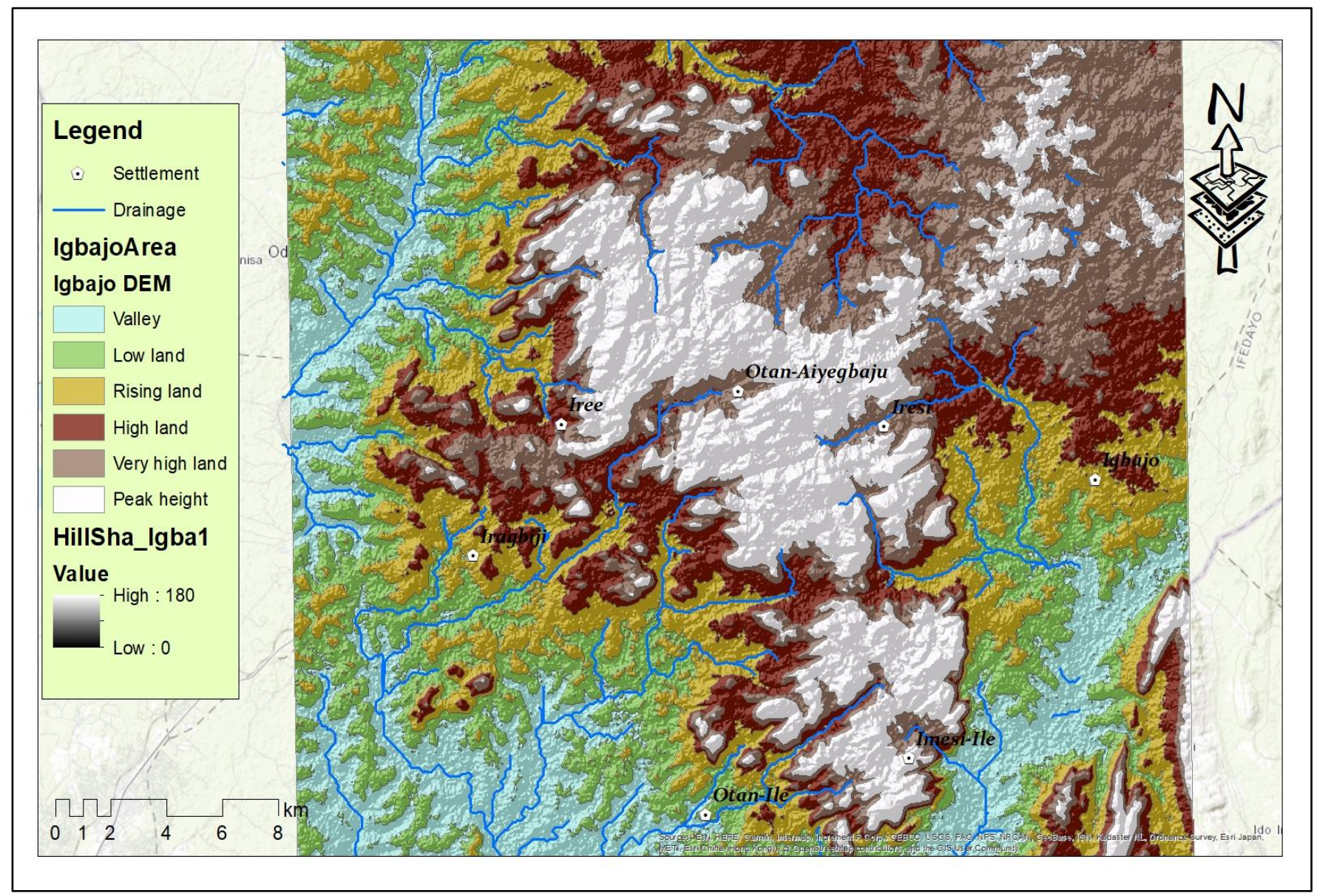

Figure 5: Digital Elevation Model (DEM) shows the Igbajo pluton distinctly as an elongate structure dissected by outflowing rivers in the margins, and with a core at the centre. 


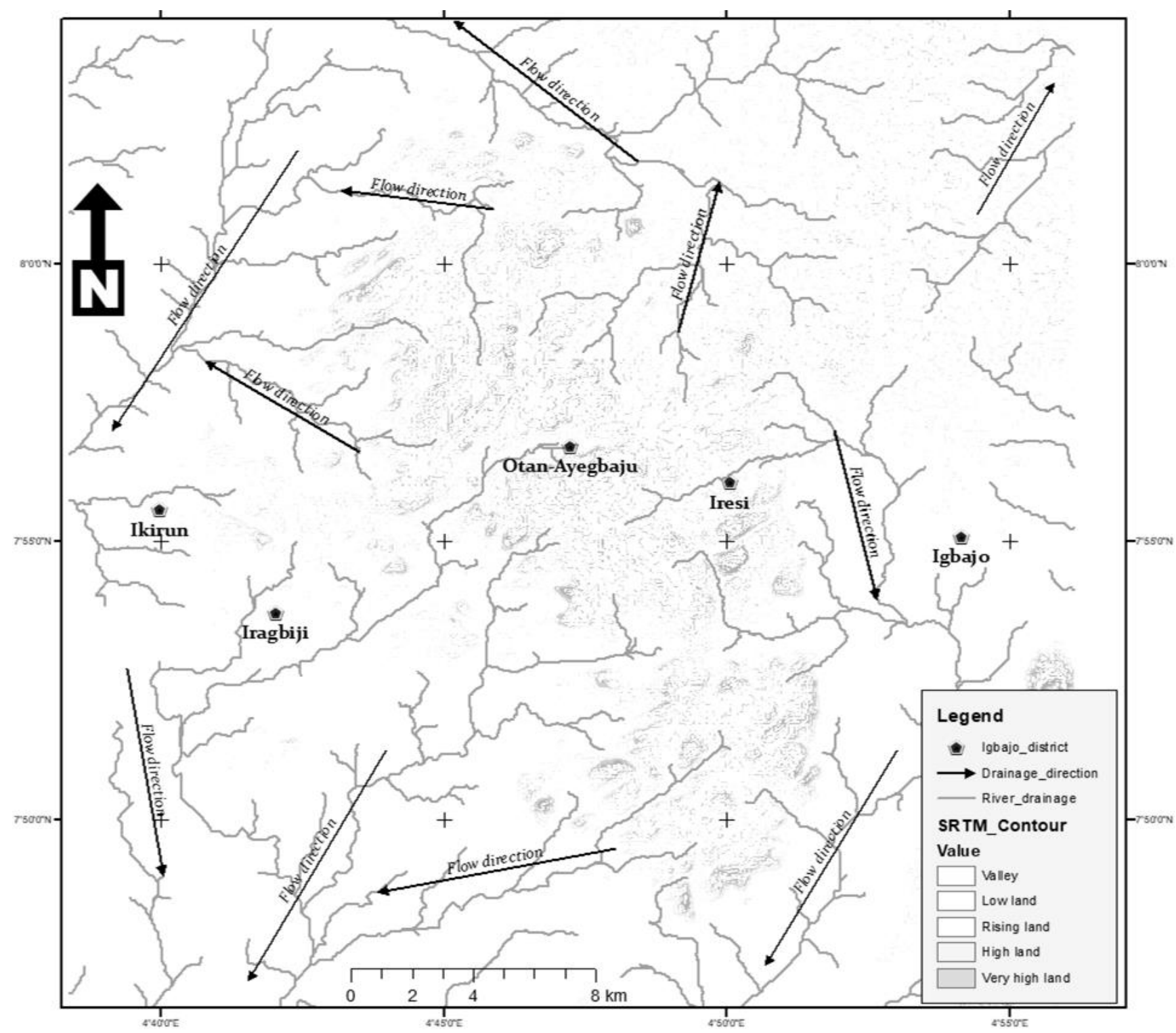

Figure 6: Showing the various directions of flow of the regional drainage while also emphasising the relationship between river drainage network and the location of the highest points in the region.

\section{Discussion}

\section{Spatial distribution of inselbergs}

The study attempted an evaluation of the spatial distribution of inselbergs in Igbajo District of the Western Nigerian Basement region. Central to the objective of this study is the understanding that 
the spatial distribution of residual landforms like inselbergs is usually controlled by the structure and lithology of the underlying geology as well as the intricate evolutionary processes that engendered the landforms. Overall, the analysis revealed that inselbergs in the Igbajo District of Western Nigeria basement complex are clustered in their distribution over space. It is also affirmed that by obtaining similar results from multiple analyses (i.e. PPD and NNA); the analytical approaches adopted had not had any significant influence on the findings from this study. Of critical essence, therefore, is the significance of this result to explaining the probable processes of landform evolution. To this end, the current result differs from that obtained in a similar analysis over the entire basement region of Western Nigeria (Faniran, 1974), where the observed patterns range from random to regular and was inferred to indicate inselberg's evolution via two-stage process. Positively, present finding agrees with a later study on the Zimbabwe's inselberg landscape (Romer, 2005).

The challenge, therefore, is whether the hypothesis (sensu Faniran, 1974) is valid for the determination of inselbergs' mode of evolution. This is critical, as the present study would suggest that evolution of inselbergs is via scarp retreat and pedimentation. Such claim would contrast with field observations from previous authors in this and similar environment who have alluded to several irrevocable proofs of the two-stage process of deep weathering and stripping (e.g. Jeje, 1973; Thomas, 1978, 1994; Twidale, 1998; Romer, 2010). Moreover, Romer (2005) stated that clustering of inselbergs could be indicative of the two-stage model of evolution. In this regard, observed clusters were related to structural and lithological differences, and associated with specific plutonic bodies. The evolutionary pathways of these kinds of residual outcrops according to the author, normally involve differential weathering and erosion, the twin processes of the twostage model of inselberg evolution. 
The role of rock lithology and structure in the development of inselbergs is also significant (Jeje, 1973; Thomas, 1978; Romer, 2007). In essence, for inselbergs built on homogenous geology e.g. granitoid rocks variability in later-exposed features is determined by structures such as density of fractures, which are usually exploited by chemical denudation, and variability in the susceptibility of rocks as informed by petrography (i.e. relating to mineralogy, texture, grain size and composition) (Pye et al. 1984; Romer, 2005, 2010). For instance, in Zimbabwe, Romer (2007) associated differences in the frequency of inselberg clusters to the age of the parent granitoid rocks: younger granitoid rocks are characterised by an abundance of clusters while older granitoids rarely formed clusters. The determinant factor appeared to be the mineralogical composition of the two granitoid versions, with the younger granites composed largely of chemically resistant k-feldspars while having low composition of less resistant plagioclase minerals (Romer, 2007). The geology of the present study site has been affirmed to show progressive gradation into surrounding less resistant rocks, a factor indicating zones of mixed lithology and possible weak resistance to chemical denudation in the fringes (de Swardt, 1954; Afolabi and Ogunkoya, 2018). Differences in lithology and fracture density as induced by the emplacement of the granitic pluton within the country rock are capable of making the fringes of the plutonic body more susceptible to degradation than the core part of the rock mass. This could result into clustering of inselbergs in zones with subsisting favourable conditions.

\section{River drainage network and Inselbergs spatial location}

In order gain a better understanding on the probable role played by the structure of the underlying geology in the mode of inselberg development, a visualization of the river drainage network pattern in relation to inselbergs' distribution is attempted. Analysis of the drainage network (Fig. 5) appeared to show that stream networks have exploited the planes of weakness in the parent pluton 
thereby leaving clusters of high-rising inselbergs in the centre following prolonged degradation from the fringes in agreement with the scarp retreat idea (King, 1975). Previously, similar analysis had revealed inselbergs located in various physiographic settings such as river valleys, regional high lands, and the lack of physiographic bias was held to be diagnostic of structurally controlled subsurface evolution (Jeje, 1973). In effect, the clusters of high-rising inselbergs in the central parts, and of more degraded landforms in the fringes in the present study site point to the landscape as having evolved via scarp retreat. This hypothesis is however faulted as the landforms in question were known to have been carved out of a deep-seated plutonic body (de Swardt, 1953; Afolabi et al., 2013), and the basement terrain of Western Nigeria is not known to have witnessed episodes of uplift by which the deep-seated pluton could have been brought to the surface.

Added to this is the fact that previous studies in the region have documented evidence of formerly deeply weathered profiles especially at road construction sections and river channel beds where sound (unweathered) rocks yet to be exposed from under the cover of weathered materials were observed (Thomas, 1994; Afolabi and Ogunkoya, 2018). It can, therefore, be deduced that the initial pluton had been deeply weathered beneath the surface, and later exposed during subsequent interpluvial (dry) periods to reveal the inselbergs. Subsequent evolution of the inselberg landscape appeared to have involved fluvial drainage imposition on planes of weakness, and lateral denudation, in agreement with King's (1975) evolution idea. In the final analysis, the argument presented here aligns with the third school of thought (Thomas, 1978) that posited that inselbergs are landforms, which may evolve through varying processes acting within different landscapes. Thomas (ibid) further added that it is highly probable that inselbergs have evolved through a sequence of processes (often seen as mutually exclusive) during the different stages of their development. This idea, linked to the principle of equifinality (Bertalannffy, 1950) provides a more 
plausible and less confrontational view on inselberg evolution in the present study site and related tropical landscapes as well.

\section{Conclusion}

The spatial distribution of inselbergs formed the focus of point pattern analyses carried out in this study. Attempt was made to validate the age-long supposition that pattern of distribution provides clues in unravelling the underlying processes behind the evolution of inselberg landforms. The main finding from this study is that inselbergs in Igbajo district, Western Nigeria have a clustered pattern of distribution. In the light of this, we can conclude that:

On an individual massif or pluton built on homogenous geology, inselbergs are distributed in clusters as informed by the structure of the underlying rocks.

In contrast, geologically heterogeneous spatial scale, distribution of inselbergs may follow a random pattern as informed by the spatial variation in the underlying geology.

It is also proposed that, in either of the preceding cases, observed spatial distribution pattern does not necessarily diminish or nullify the role of subsurface weathering in the evolution of inselbergs.

Finally, it is emphasised that spatial distribution pattern of inselbergs may only lend some credence to the claims of alternative evolutionary pathways for the landforms but does not offer a standalone solution to the critical question of how inselbergs have evolved over geologic time.

\section{Acknowledgement}

The authors wish to convey their sincere appreciation to the reviewers whose critical and insightful comments greatly enhanced the revision of the paper as well as to the Editorial Team for their insightful comments on the final draft of the paper. 


\section{References}

Afolabi, M. R., \& Ogunkoya, O. O. (2018). Morphology and evolution of inselbergs on a part of the Basement Complex of Western Nigeria. Zaria Geographer, 25(1), 13-27.

Afolabi, O. A., Abimbola, A. F., Olatunji, A. S., Sanusi, R. B., Shomuyiwa, E. O., \& Ohunayo, O. (2013). Evidences of Metasomatic Processes during the Emplacement of Pan-African Granites in the Eastern End of the West African Craton. Journal of Environment\& Earth Science, 3(8), 24-31.

Bertalannfy, L. (1950). The theory of open systems in physics and biology. Science, 111, 23-29.

Budel, J. (1957). Double Surfaces of Levelling in the Humid Tropics ("Die doppelten Einebnungsflachen in den feuchten Tropen”). In G. E. Adams (Ed.), Planation Surfaces; Peneplains, Pediplains and Etchplains (pp. 361-366). Dowden Hutchingson \& Ross.

Burke, K., \& Durotoye, B. (1970). Boulder slide on an inselberg in the Nigerian Rain Forest. Journal of Geology, 78, 733-735.

Clark, P. J., \& Evans, F. C. (1954). Distance to Nearest Neighbour as a Measure of Spatial Relationships in Populations. Ecology, 35(4), 445-453.

de Swardt, A. M. D. (1953). The Geology of the Country around Ilesha. Geological Survey of Nigeria Bulletin, 23.

Doornkamp, J. C. (1968). The Role of Inselbergs in the Geomorphology of Southern Uganda. Transaction of the Institute of British Geographers, 44, 151-162.

Faniran, A. (1974). Nearest-neighbour Analysis of Inter-Inselberg Distance; a case study of Inselbergs of South Western Nigeria. Zeit Fur Geomorphologie N. F, Supplement, 20, 150167.

Hugget, R. J. (2007). Fundamentals of Geomorphology (3rd ed.). Routledge, Taylor \& Francis.

Jeje, L. K. (1973). Inselbergs' Evolution in a Humid Tropical Environment; the example of Southwestern Nigeria. Zeit Fur Geomorphologie N. F. Supplement, 17(2), 194-225.

King, L. C. (1957). Canons of Landscape Evolution. Geological Society of America Bulletin, 64, 721-752.

King, L. C. (1975). Bornhardt Landforms and What they teach. Zeit. Geomorph.N. F.Berlin Stuttgart, 19(3), 300-318.

Linton, D. L. (1955). The Problem of Tors. Geographical Journal, 121, 470-487.

Migon, P. (2006). Geomorphological Landscapes of the World: Granite Landscapes of the World (1st ed.). Oxford: University Press.

Ollier, C. D. (1978). Inselbergs of the Namib Desert, processes, and history. Zeitschrift Fur Geomorphologie, Supplement, 31, 161-176.

Owen, S. C. (2014). Geological Origins of Sugarloaf Mountains in Eastern Brazil and their Environmental Significance as Refugia for the Mata Atlantica Rainforest. Unpublished $\mathrm{PhD}$ Thesis, University of Leicester, United Kingdom. 
Pye, K., Goudie, A. S., \& Thomas, D. S. G. (1984). A test of petrological control in the development of bornhardts and koppies on the Matopos Batholith, Zimbabwe. Earth Surface Processes and Landforms, 9, 455-467.

Rahaman, M. A. (1976). Review of the Basement Geology of Nigeria. In C. A. Kogbe (Ed.), Geology of Nigeria (pp. 41-57). Elizabethan Publishers, Lagos.

Rogerson, P. A. (2001). Statistical Methods for Geography. London: Sage Publishers.

Romer, W. (2005). The distribution of inselbergs and their relationship to geomorphological, structural, and lithological controls in Southern Zimbabwe. Geomorphology, 72, 156-176.

Romer, W. (2007). Differential weathering and erosion in an inselberg landscape in southern Zimbabwe: A morphometric study and some notes on factors influencing the long-term development of inselbergs. Geomorphology, 86, 349-368.

Romer, W. (2010). Multiple planation surfaces in basement regions: Implications for the reconstruction of periods of denudation and uplift in southern Zimbabwe. Geomorphology, $114,199-212$.

Shaw, G., \& Wheeler, D. (1994). Statistical techniques in Geographical Analysis. London: David Fulton Publishers.

Silk, J. (1979). Statistical Concepts in Geography (1st ed.). London: George Allen and Unwin.

Thomas, M. F. (1966). Some Geomorphological Implications of Deep Weathering Patterns in Crystalline Rocks in Nigeria. Transactions of the Institute of British Geographers, 40, 173193.

Thomas, M. F. (1978). The Study of Inselbergs. Zeit. Geomorphologie N. F. Berlin Stuttgart, Supplement Bd., 31, 1-41.

Thomas, M. F. (1994). Geomorphology in the Tropics: A Study of Weathering and Denudation in Low Latitudes (2nd ed.). Chichester: John Wiley and Sons.

Twidale, C. R. (1982). The Evolution of Bornhardts. American Scientist, 70(3), 268-276.

Twidale, C. R. (1998). Granitic bornhardts: their morphology, characteristics, and origins. Geological Society of Malaysia Bulletin, 42, 237-255.

Twidale, C. R., \& Bourne, J. A. (1975). The Subsurface Initiation of some Minor Granite Landforms. Journal of the Geological Society of Australia, 22(4), 477-484.

Twidale, C. R., \& Bourne, J. A. (1976). The Shaping and Interpretation of large Residual Granite Boulders. Journal of the Geological Society of Australia, 23(4), 371-381. 